\title{
Frontal horn thin walled cysts in preterm neonates are benign
}

\author{
B R Pal, P R Preston, M E I Morgan, D I Rushton, G M Durbin
}

\begin{abstract}
Background-Screening cranial ultrasound led to the discovery of isolated frontal horn cysts quite distinct from periventricular leucomalacia cysts.

Aim-To clarify their significance, incidence, characteristics, causal factors or aetiology, and effect on long term outcome.

Design-A retrospective observational study of all first cranial ultrasound scans (total of 2914) performed during the period 1984-1994 inclusive found 21 neonates with smooth thin walled frontal horn cysts: 18 of 2629 scanned were of birth weight $<1500 \mathrm{~g}$ or gestation $<33$ weeks, and three of 285 were $>33$ weeks gestation. Sequential ultrasound, maternal records, and neonatal events were retrospectively assessed. In survivors, routine neurodevelopmental evaluations were obtained. Postmortem studies of one cyst were performed to determine the nature and origin of these lesions.
\end{abstract}

Results-Of the 21 subjects, 15 had isolated frontal horn cysts and six had additional ultrasound scan abnormalities, including four with subependymal haemorrhage. The sonographic features of frontal horn cysts were of distinctive morphology (elliptical, smooth, thin walled, ranging in size from 3 to $20 \mathrm{~mm}$ ) and position (adjacent to the tip of the anterior horns). The cysts enlarged and then regressed by a median corrected age of 2 months. Subjects of $<33$ weeks gestation $(n=18)$ had a median birth weight of $1465 \mathrm{~g}$ (range 720-1990) and median gestation of 30 weeks (range 24-32). There was no consistent perinatal course. The neurodevelopmental outcome in 10 of the 11 survivors with isolated frontal horn cysts was normal. Five subjects died from causes unrelated to brain pathology in the neonatal period, and one subject died after infancy. Histological examination of a cyst at autopsy in one additional subject subsequent to the period of study confirmed the cyst to be lined by neuroblasts and ependymal cells.

Conclusions-The incidence of frontal horn cysts in this low birthweight population was 7 per $1000(0.7 \%)$ subjects scanned. They are present in the first week of life, enlarge, and resolve spontaneously. Survivors with isolated frontal horn cysts appear to have normal neurodevelopmental outcome. The prognosis of these distinct frontal horn cysts therefore appears to be benign.

(Arch Dis Child Fetal Neonatal Ed 2001;85:F187-F193)
Keywords: frontal horn cysts; preterm; cranial; ultrasound; brain

Survival rates of low birthweight and preterm infants are improving, but the rates of neurodevelopmental disability remain unchanged. ${ }^{1}$ Cranial ultrasound may be a useful predictor of major handicap. ${ }^{23}$ Sonographically determined rates of severe cerebral abnormality now range from 10 to $83 \%$ at 23 weeks and 10 to $22 \%$ at 25 weeks gestation ${ }^{1}$ and were recently estimated at $1.1 \%$ if the infant was born after 29 weeks gestation. ${ }^{4}$ Periventricular leucomalacia (PVL) has been well reviewed. ${ }^{56}$ In a previous report, we described the pathophysiological evolution of PVL. ${ }^{7}$ Sequential sonography shows that PVL lesions can be echodense initially and become cystic during the next one to four weeks. The extent of periventricular cysts is often related to the type and severity of motor and cognitive disabilities. ${ }^{8}$

The distinctive lesion of thin walled frontal horn cysts seen sonographically within the first week of life has not been well documented to date. Keller and colleagues ${ }^{9}$ identified 11 infants with frontal horn cysts, but four of these had other associated cranial abnormalities, and six were lost to follow up before 2 months of age. More recently, Sudakoff et $a l^{10}$ described a series of seven premature infants $(<36$ weeks gestation) with isolated frontal horn cysts found within 24 hours of birth. They showed that although mild neurological deficiencies were present during the first year of life, but clinical assessment at one year in those subjects available for follow up revealed no neurological impairment. The cause of these frontal horn cysts remains unclear, and long term outcome is not known. We report a series of 21 cases with frontal horn cysts seen within the first week of life, and give the ultrasound findings, long term clinical follow up, and histological evidence of the cause.

Methods and subjects

Hard copies of all first cranial ultrasound scans performed on the neonatal unit at Birmingham Womens' Hospital between 1984 and 1994 inclusive were retrospectively reviewed. All neonates of $<1500 \mathrm{~g}$ birth weight and $<33$ weeks gestation were scanned, and also a few larger babies admitted for intensive care. Cranial ultrasound examinations were performed using an ATL Mark III small wheel sector scanner with a $5 \mathrm{MHz}$ transducer until 1988 and a Hewlett-Packard phased focused array system with 5 and $7.5 \mathrm{MHz}$ transducer thereafter. The method used and our experience at this unit have been previously reported. ${ }^{7}$ A series of views (coronal and sagittal 
images) were routinely obtained on each examination, and images documented on silver paper, thermal image paper, and videotape. The cranial scans were screened initially by one sonologist (PRP) for the presence of frontal horn cysts.

From a total of 2914 first scans (2629 were of neonates of gestation $<33$ weeks and birth weight $<1500 \mathrm{~g} ; 285$ were of neonates of 33 weeks gestation and above), 21 neonates were identified with frontal periventricular cysts. Two neonatologists (MEIM, GMD) familiar with neonatal cranial ultrasound reviewed the scans independently to validate the findings. Sequential ultrasound examinations were reviewed by PRP to identify the development of other intracranial abnormalities and the progress of these frontal horn cysts.

The records of these neonates along with maternal records were retrospectively reviewed for maternal risk factors and complications before or during delivery.

In survivors, information on neurodevelopment up to age 3 years was obtained. Evaluations used included: Denver scales; physiotherapy assessment based on the Nelson-Ellenberg method ${ }^{11}$ and the Christmas modification with Bobath concept; and independent assessment by modified Griffiths test results from community paediatric records. Subsequent development was ascertained by contacting their current general practitioner/ school.

\section{Results}

Table 1 shows the characteristics of the 21 subjects. Analysis of antenatal/perinatal events did not show any consistent risk factors. As subject C was exactly 33 weeks gestation and weighed $1500 \mathrm{~g}$, he was classified in the large baby category. Therefore there was an incidence of $0.7 \%(18 / 2629)$ in the group of infants of $<1500 \mathrm{~g}$ birth weight or $<33$ weeks gestation, and $1.05 \%(3 / 285)$ for the group of larger babies. The subjects in the former group had a median birth weight of 1465 g (range 7201990) and median gestation of 30 weeks (range 24-32). The perinatal course included predictable gestation/age related illnesses. Antepartum haemorrhage occurred in six pregnancies, usually within 24 hours of delivery, leading to emergency lower uterine caesarean section (subjects D, F, J, L) or precipitating labour (subject $\mathrm{E}$ born by spontaneous vaginal delivery); there was only one case of a previous episode of antepartum haemorrhage at 14 weeks gestation, but the infant (subject A) was born at 31 weeks.

Table 1 Characteristics and antenatal and neonatal events of 21 subjects with frontal horn thin walled cysts

\begin{tabular}{|c|c|c|c|c|c|c|c|}
\hline Subject & $\begin{array}{l}\text { Gestation } \\
\text { (completed } \\
\text { weeks) }\end{array}$ & $\begin{array}{l}\text { Birth } \\
\text { weight (g) }\end{array}$ & Sex & $\begin{array}{l}\text { Apgar at } \\
5 \text { min }\end{array}$ & Antenatal problems & Delivery & Neonatal events \\
\hline $\mathrm{A}$ & 31 & 720 & M & 3 & APH 14 weeks, IUGR & $\begin{array}{l}\text { Breech } \\
\text { Em LUCS }\end{array}$ & $\begin{array}{l}\text { Mild IRDS: ventilated } 6 \text { days. Low glucose. } \\
\text { Exchange transfusion for sepsis }\end{array}$ \\
\hline B & 28 & 1470 & $\mathrm{~F}$ & 9 & PROM IUT for rhesus & Em LUCS & $\begin{array}{l}\text { Exchange transfusion for rhesus. Mild RDS: } \\
\text { ventilated } 4 \text { days }\end{array}$ \\
\hline $\mathrm{C}$ & $33^{\star}$ & 1500 & $\mathrm{M}$ & 9 & HBP & LUCS & TTN: 2 days \\
\hline $\mathrm{D}$ & 31 & 1700 & $\mathrm{~F}$ & 8 & $\mathrm{APH}$ & Em LUCS & $\begin{array}{l}\text { IRDS: high gentamycin levels. Anaemia. Deranged } \\
\text { clotting }\end{array}$ \\
\hline $\mathrm{E}$ & 24 & 845 & $\mathrm{~F}$ & 9 & $\mathrm{APH}$, gardnerella & SVD & $\begin{array}{l}\text { Congenital \& acquired pneumonia. Ventilated. } \\
\text { Candida }\end{array}$ \\
\hline $\mathrm{F}$ & 27 & 965 & M & 9 & $\mathrm{APH}$ & Em LUCS & $\begin{array}{l}\text { Severe IRDS: ventilated, pneumothoraces/PIE/ } \\
\text { BPD }\end{array}$ \\
\hline G & 31 & 1830 & $M$ & 8 & Maternal pyrexia & Em LUCS & Congenital pneumonia: ventilated 24 hours \\
\hline $\mathrm{H}$ & 32 & 1990 & M & 9 & Hyperemesis, HBP & $\begin{array}{l}\text { Assisted } \\
\text { breech }\end{array}$ & IRDS: ambient $\mathrm{O}_{2} 5$ days. Jaundice, phototherapy \\
\hline I & $42^{\star}$ & 3760 & $\mathrm{~F}$ & 9 & Consanguinous marriage & SVD & Acidosis: inherited pyroglutamic acid \\
\hline $\mathrm{J}$ & 30 & 1550 & $M$ & 9 & $\mathrm{APH}$ & Em LUCS & IRDS: ambient $\mathrm{O}_{2} 3$ days. Apnoea of prematurity \\
\hline $\mathrm{K}$ & 28 & 1460 & M & 8 & Polyhydramnios & Em LUCS & Severe IRDS: pneumothorax, hypotension/hypoxia \\
\hline $\mathrm{L}$ & 30 & 1510 & $\mathrm{~F}$ & 10 & $\mathrm{APH}$ & Em LUCS & IRDS: ambient $\mathrm{O}_{2} 5$ days. Apnoeas \\
\hline$M$ & $34^{\star}$ & 2730 & M & 9 & Consanguinous marriage & SVD & Acidosis: $\uparrow$ lactate. Fits \\
\hline $\mathrm{N}$ & 30 & 1640 & M & 9 & $\begin{array}{l}\text { Rhesus disease. Bradycardia after } \\
\text { IUT }\end{array}$ & LUCS & Ventilated: exchange transfusion $\downarrow$ BP \\
\hline $\mathrm{O}$ & 26 & 920 & $\mathrm{~F}$ & 8 & Twin pregnancy & Em LUCS & $\begin{array}{l}\text { IRDS } \downarrow \text { BP/anaemia \& apnoeas. GOR. BPD \& } \\
\text { PDA }\end{array}$ \\
\hline $\mathrm{P}$ & 32 & 1750 & $\mathrm{~F}$ & 9 & Nil & SVD & Mild jaundice. Maternal death after discharge \\
\hline Q & 31 & 1470 & $\mathrm{~F}$ & 8 & Twin pregnancy & LUCS & IRDS: ventilated 4 days \\
\hline $\mathrm{R}$ & 31 & 1360 & $\mathrm{~F}$ & 9 & Twin pregnancy & LUCS & Mild jaundice \\
\hline S & 28 & 1000 & $\mathrm{~F}$ & 7 & Twin pregnancy & LUCS & $\begin{array}{l}\text { Congenital pneumonia: ventilated } 3 \text { days. Twin } \\
\text { died Group B streptococcus }\end{array}$ \\
\hline $\mathrm{T}$ & 31 & 750 & $\mathrm{~F}$ & 9 & Twin pregnancy & $\begin{array}{l}\text { Breech } \\
\text { LUCS }\end{array}$ & IUGR/hypoglycaemia \\
\hline $\mathrm{U}$ & 28 & 1040 & $\mathrm{~F}$ & 9 & Maternal drugs & SVD & SVT $R_{\mathrm{x}}$ Digoxin. ASD/PDA \\
\hline \multicolumn{8}{|l|}{ Summary } \\
\hline $\begin{array}{l}\text { Subjects } \\
<33 \text { weeks } \\
\text { gestation } \\
(n=18)\end{array}$ & $\begin{array}{l}\text { Gestation } \\
\text { (weeks) }\end{array}$ & $\begin{array}{l}\text { Birth } \\
\text { weight (g) }\end{array}$ & Sex & Apgar & Antenatal problems & Deliveries & \\
\hline $\begin{array}{l}\text { Median } \\
\text { Ranges }\end{array}$ & $\begin{array}{l}30 \\
(24-32)\end{array}$ & $\begin{array}{l}1465 \\
(720- \\
1990)\end{array}$ & $7 \mathrm{M} 11 \mathrm{~F}$ & $\begin{array}{l}9 \\
(3-10)\end{array}$ & 5 Twin, $6 \mathrm{APH}$ & \multicolumn{2}{|c|}{14 LUCS: 9 emergency } \\
\hline
\end{tabular}

${ }^{\star}$ Subjects $\mathrm{C}, \mathrm{I}, \mathrm{M}$ are not included in the summary table.

Em LUCS, Emergency lower uterine caesarean section; IRDS, idiopathic respiratory distress syndrome; APH, antepartum haemorrhage; HBP, hypertension; IUGR, intrauterine growth retardation; PROM, premature rupture of the membranes; IUT, intrauterine transfusion; RDS, respiratory distress syndrome; ambient $\mathrm{O}_{2}$; GOR, gastro-oesophageal reflux; BPD, bronchopulmonary displasia; PDA, patent ductus arteriosus; SVT, supraventricular tachycardia; ASD, atrial septal defect. 
Table 2 Ultrasound characteristics of frontal horn cysts in 21 neonates

\begin{tabular}{|c|c|c|c|c|}
\hline Subject & First scan (age) & $\begin{array}{l}\text { Features and largest } \\
\text { diameter }\end{array}$ & Other ultrasound findings & Scan progress \\
\hline A & Day 1 & Bilateral single $\mathrm{L}>\mathrm{R}$ & SEH & Enlarged to $18 \mathrm{~mm}$ by 3 weeks, resolution by 3 months \\
\hline B & Day 7 and 1 month & L side solitary $6 \mathrm{~mm}$ & Nil & FHC present day 30, resolution by 5 months \\
\hline $\mathrm{C}$ & Day 5 & $\mathrm{~L}$ side 2 cysts $4 \mathrm{~mm}$ & R SEH & \\
\hline $\mathrm{D}$ & Day 3 & $\mathrm{~L}$ side single $10 \mathrm{~mm}$ & Nil & $\begin{array}{l}2 \text { smaller cysts appeared at } 3 \text { weeks, all resolved at } 4 \\
\text { months }\end{array}$ \\
\hline $\mathrm{E}$ & Day 2 & $\mathrm{R}$ side 2 cysts $3 \mathrm{~mm}$ & Nil & $10 \mathrm{~mm}$ size by 4 weeks \\
\hline $\mathrm{F}$ & Day 2 & Bilateral 3L 2R $5 \mathrm{~mm}$ & $\mathrm{R} \mathrm{SEH} /$ caudate nucleus dense at $2 \mathrm{~m}$ & $\begin{array}{l}\text { FHC increased to } 1.4 \mathrm{~mm} \text { at } 4 \text { weeks, resolved by } 5 \\
\text { months }\end{array}$ \\
\hline G & Day 7 & $\mathrm{R}$ side 2 cysts $20 \mathrm{~mm}$ & Nil & NA \\
\hline $\mathrm{H}$ & Day 2 & $\mathrm{~L}$ side; single $13 \mathrm{~mm}$ & Nil & NA \\
\hline I & Day 14 & Bilateral, $10 \mathrm{~mm}$ & PM ultrasound & NA \\
\hline $\mathrm{J}$ & Day 2 & Bilateral, 2R 1L, $11 \mathrm{~mm}$ & Nil & No change at 4 weeks \\
\hline K & Day 3 & Bilateral, $2 \mathrm{R}, 1 \mathrm{~L}$ & Nil & NA \\
\hline $\mathrm{L}$ & Day 2 & $\mathrm{~L}$ side, single $16 \mathrm{~mm}$ & Nil & No change at 1 week, resolved 2 months \\
\hline M & Day 3 & $\mathrm{~L}$ side, $23 \mathrm{~mm}$ & $\begin{array}{l}\text { R SEH wide IHF, parietal subarachnoid } \\
\text { space }\end{array}$ & NA \\
\hline $\mathrm{N}$ & Day 1 & Bilateral & Nil & NA \\
\hline $\mathrm{O}$ & Day 1 & Bilateral, 2L, 1R 2 mm & Nil & $12 \mathrm{~mm}$ size at 2 weeks, regressed by 10 weeks \\
\hline $\mathrm{P}$ & Day 3 & $\mathrm{~L}$ side, single, $3 \mathrm{~mm}$ & Not seen on day 2 scan & $7 \mathrm{~mm}$ at 4 weeks, no further scans \\
\hline $\mathrm{Q}$ & Day 3 & L side, multiple, $5 \mathrm{~mm}$ & Bilateral. SEH & Bilateral PVL cysts after 2 weeks \\
\hline $\mathrm{R}$ & Day 2 & Bilateral, 2R, $1 \mathrm{~L}$ & Nil & NA \\
\hline S & Day 2 & Bilateral, 1L, 2R, $9 \mathrm{~mm}$ & Nil & Resolved at 4 months \\
\hline $\mathrm{T}$ & Day 3 & $\mathrm{R}$ side, single $8 \mathrm{~m}$ & R SEH & Resolved \\
\hline $\mathrm{U}$ & Day 1 & $\mathrm{~L}$ side, single $6 \mathrm{~mm}$ & Nil & Resolved \\
\hline
\end{tabular}

APPEARANCES

The scans of 21 subjects showed frontal horn cysts ranging in size from 2 to $18 \mathrm{~mm}$ on the lateral border or floor of the anterior horn; 12 were unilateral (nine left, three right) and nine bilateral (table 2). In most cases, there were typically one or two cysts which appeared elliptical, thin walled, and smooth with no associated distortion of the ventricle and often following the curve of the ventricle. Figure 1 illustrates the initial ultrasound appearance in three subjects, I, $\mathrm{R}$, and $\mathrm{S}$. Routine ultrasound was carried out in the first week of life and then weekly until 6 weeks postnatal age or 33 weeks gestation; after discharge, 6-12 weekly scans were performed until 6 months corrected age. Figure 2 (subject O) and table 2 show progression of frontal horn cyst size: where serial ultrasound was obtained, the characteristics remained constant but the cysts enlarged up to a gestational age equivalent of 34 weeks (range 28-40) then regressed by a median corrected age of 2 months (range 34 weeks to 4.5 months). Subject B had only two scans (day 7 and day 28) available for review; subject I died and had one additional cranial ultrasound performed after death.

Of 21 subjects, 15 had isolated frontal horn cysts on routine scan. Six subjects had additional brain ultrasound scan abnormalities: subject $\mathrm{Q}$ had subependymal haemorrhage $(\mathrm{SEH})$ and then PVL cysts appearing at 2 weeks of age; subject $\mathrm{F}$ had SEH and caudate nucleus density; a further four subjects had SEH which resolved and their outcome is reported.

OUTCOMES

Table 3 gives the outcomes. Of the six deaths, five (subjects E, I, K, M, N) were within the neonatal period. Subject B died in an accident at 1.9 years of age and therefore her outcome is included with the 15 subjects who survived to long term follow up.

Eleven of these 16 subjects had isolated frontal horn cysts; 10 had normal development during the follow up, and one (subject $\mathrm{O}$ ) developed mild diplegia (26 week gestation twin). A further three survivors (subjects A, C, T) had additional SEH, which subsequently resolved, and they are normal at follow up. Subject F, who had SEH and caudate nucleus density on ultrasound scan, had delayed motor milestones and has a persisting mild diplegia, but attends normal school and his visual and language skills are excellent; finally subject Q had SEH and PVL and on follow up has spastic diplegia.

POSTMORTEM AND HISTOLOGICAL EXAMINATION Six babies died of causes unrelated to brain pathology: subject $B$ as the result of a road traffic accident (aged 1.9 years); subject $\mathrm{E}$ from overwhelming candidal septicaemia (day 28); subject I with inherited pyroglutamic aciduria (day 14); subject $\mathrm{K}$ with severe idiopathic respiratory distress syndrome and hypotension (day 7); subject $M$ with inherited non-ketotic hyperglycinaemia (day 7); subject $\mathrm{N}$ with severe rhesus disease (day 1).

Three of these subjects had routine postmortem examinations. The frontal horn cysts were not identified on routine postmortem examination probably because fixation resulted in collapse of the cysts. After identification of the ultrasound series of 21 subjects, an additional preterm baby of 28 weeks gestation died of a massive intraventricular haemorrhage on day 2 but had bilateral frontal horn cysts on the first ultrasound scan on day 1 (fig 3A); a postmortem examination was carried out to search for the frontal horn cysts. Figure 3B shows the histological features of the frontal horn cyst. The cyst identified lies within the periventricular white matter adjacent to the ventricle without distorting the adjacent tissues. The cyst is lined by nodules of neuroblasts, on the surface of which are occasional cells with ill defined processes consistent with blephoroplasts, suggesting an ependymal origin. There is no evidence of recent or old haemorrhage in or around the cysts. 
A
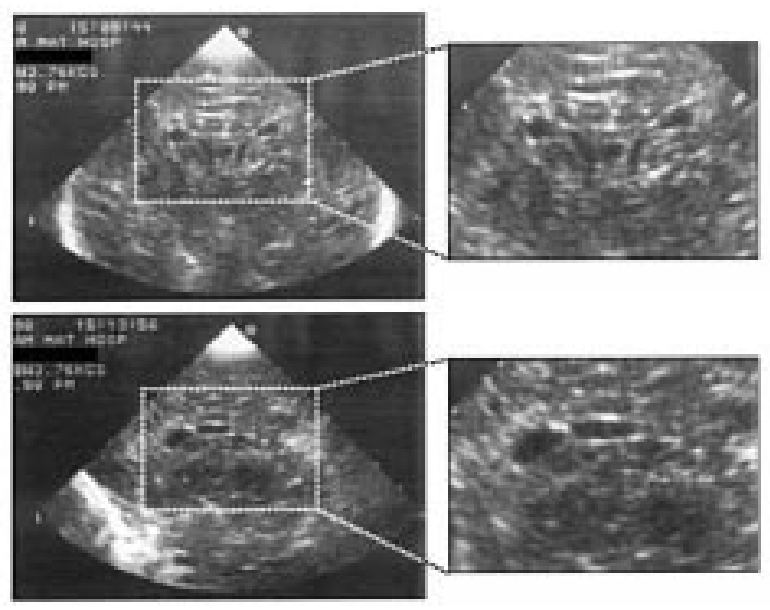

B
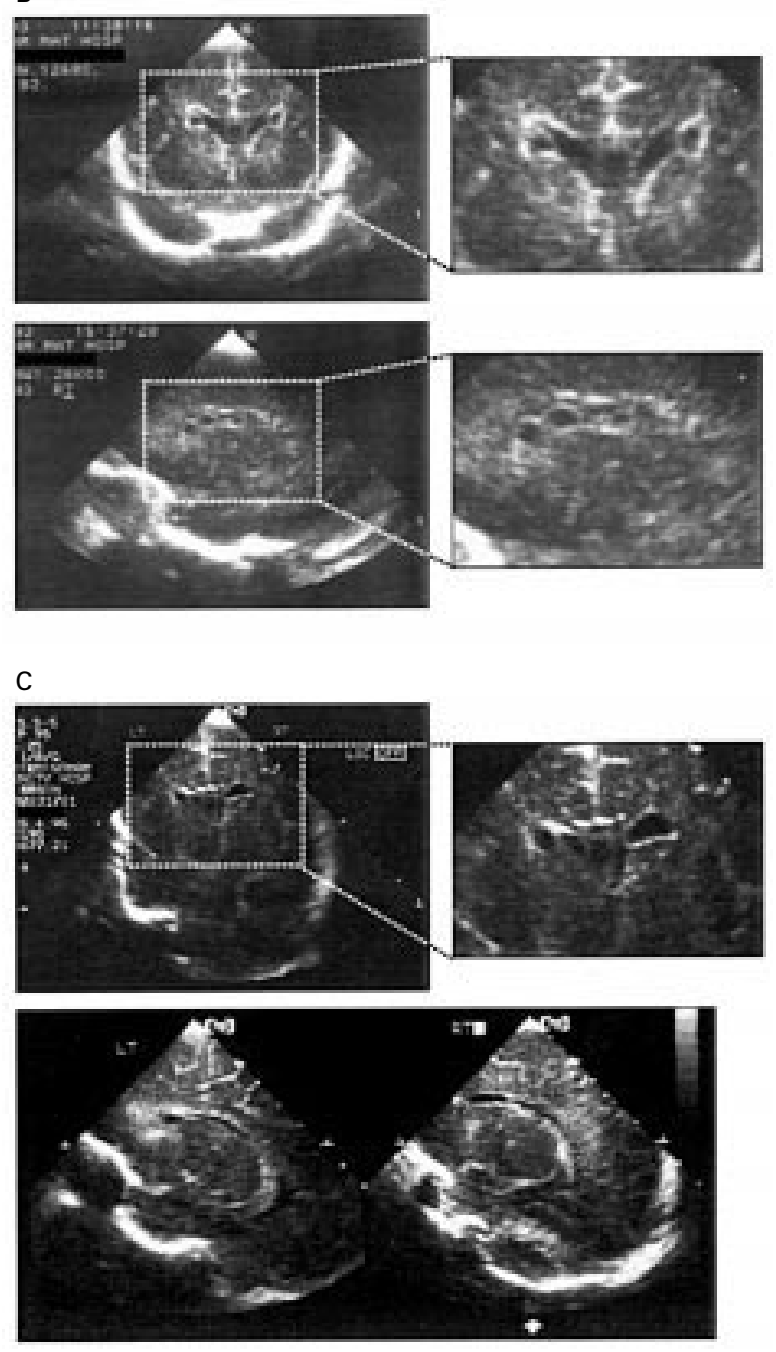

Figure 1 Frontal horn cysts as seen on coronal and parasagittal views during cranial ultrasound examination in the first week of life. Note the elliptical, smooth, thin walled appearance and the position adjacent to the tip of the anterior horn of the lateral ventricle characteristic of frontal horn cysts.

Magnification inserts show: (A) the distinct separation from the lateral ventricle that is characteristic of frontal horn cysts; (B) multiple small cysts (subject $R) ;(C)$ typical appearance of bilateral cysts (subject S). CSP, cavum septum pellucidum; FHC, frontal horn cyst; LS, longitudinal sulcus; LV, lateral ventricle.

\section{Discussion}

Our population of 2914 babies who underwent routine cranial ultrasound screening at Birmingham Maternity Hospital during the period 1984-1994 inclusive consisted of 2629
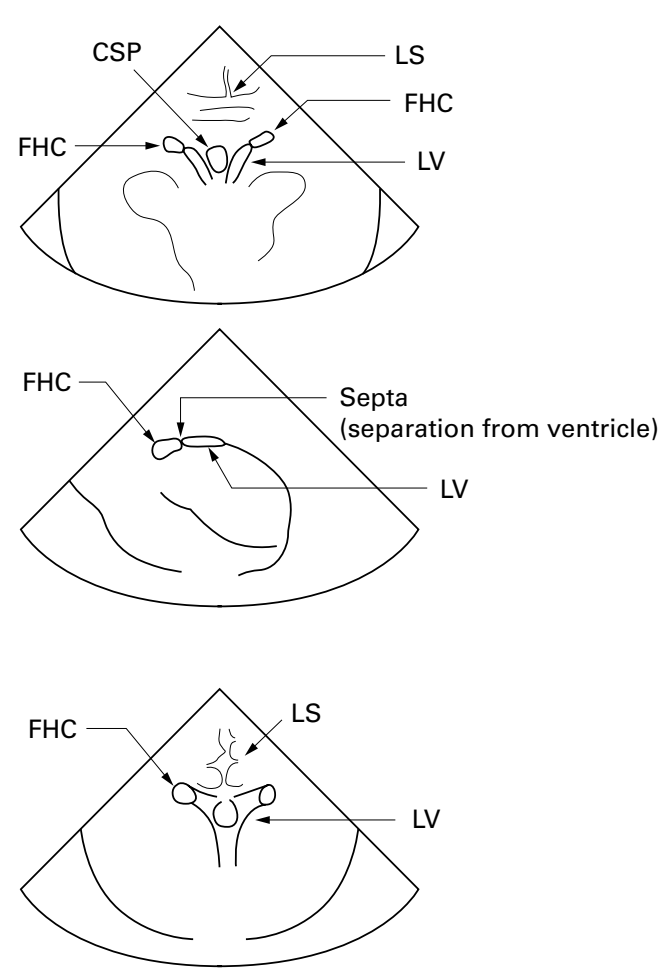

FHC -

(multiple)
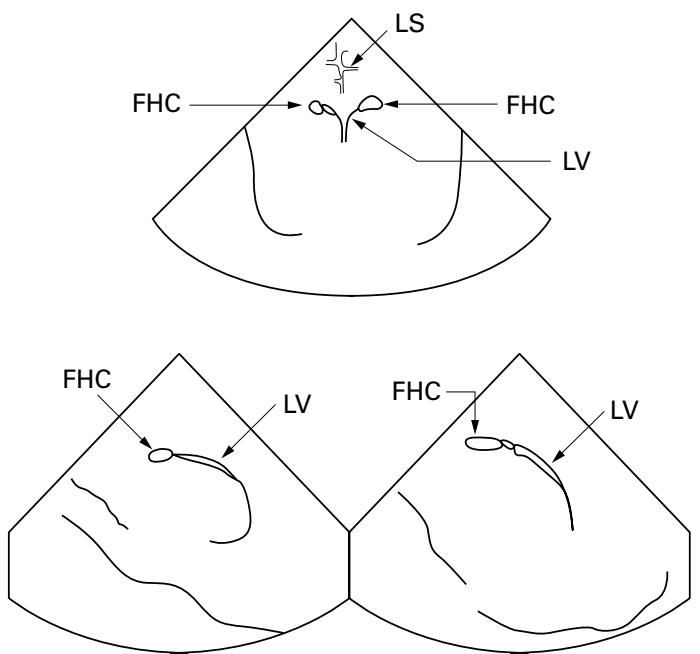

infants of birth weight $<1500 \mathrm{~g}$ or gestation $<33$ weeks and 285 term infants. This makes the incidence of unilateral or bilateral frontal horn cysts $0.7 \%$ (18/2629) for subjects of gestation $<33$ weeks or birth weight $<1500$ g, 

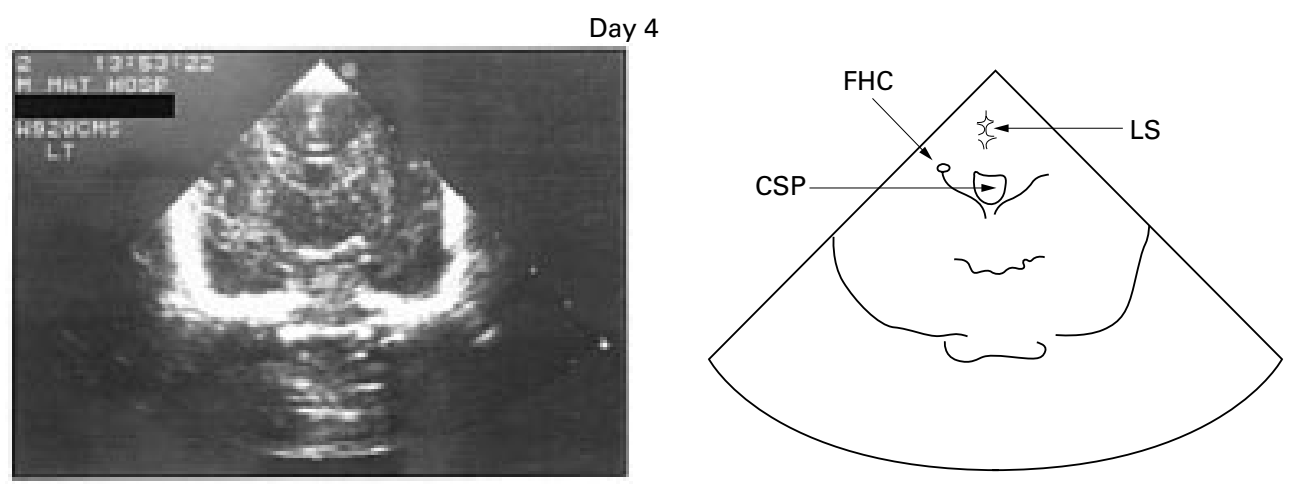

Day 14
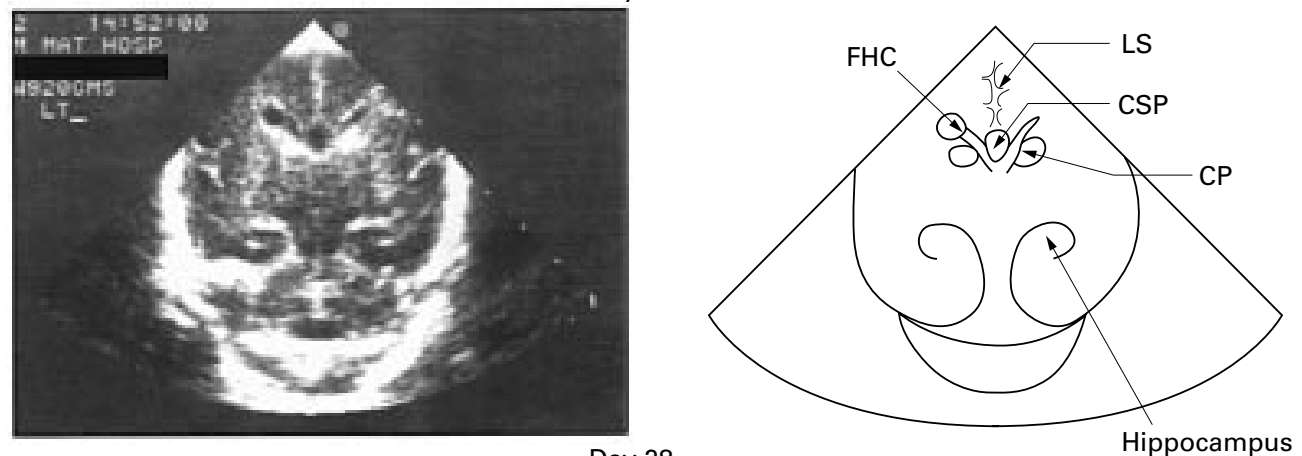

Day 28
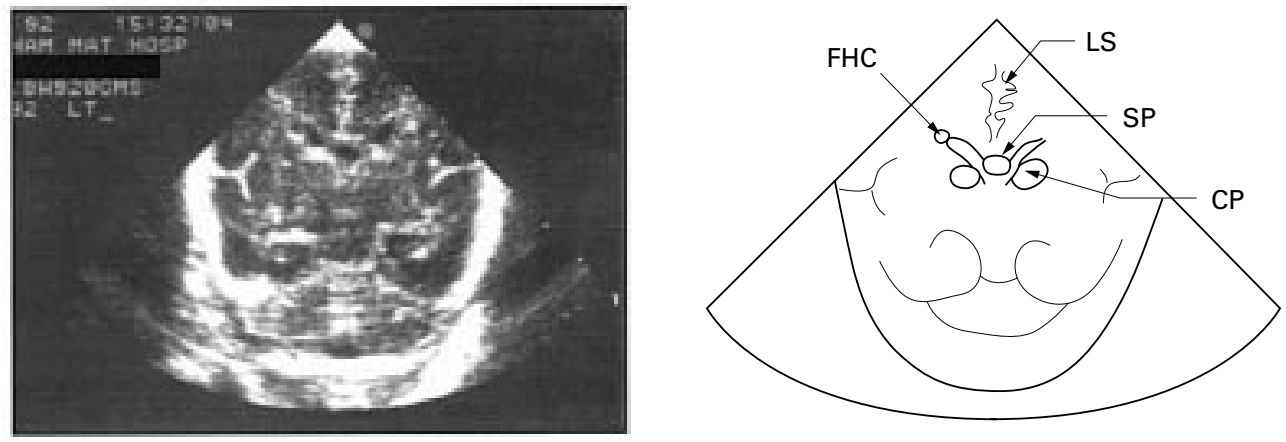

Figure 2 Progression of frontal horn cysts from week 1 to week 4 in subject $O$. Note that the characteristics of the cyst remain the same, although the size increases then regresses. CP, choroid plexus.

Table 3 Outcome and neurodevelopmental follow up for survivors

\begin{tabular}{|c|c|c|c|c|}
\hline Subject & Neonatal outcome & $\begin{array}{l}\text { Follow up age (years) } \\
\text { Birth-fune } 1999\end{array}$ & Mental/physical skills & Residual problems to date \\
\hline A & Alive & 16 & Normal. Minor speech & Nil \\
\hline B & Alive (died in road traffic accident) & 2 & Normal before death & - \\
\hline C & Alive & 14.8 & Normal. Minor speech & Nil \\
\hline $\mathrm{D}$ & Alive & 15.5 & Normal. Immature hand/eye coordination & Nil \\
\hline E & Died aged 4 weeks (candidal septicaemia) & - & - & - \\
\hline $\mathrm{F}$ & Alive & 13.0 & Late walking. Good visual \& language & Mild diplegia. Normal school \\
\hline G & Alive & 12.5 & Normal & Nil \\
\hline $\mathrm{H}$ & Alive & 11.4 & Normal & Nil \\
\hline I & Died day 14 (inherited pyroglutamic aciduria) & - & - & - \\
\hline J & Alive & 9.5 & Normal. Stridor. Aortopexy & Nil \\
\hline $\mathrm{K}$ & Died day 7 . Severe respiratory problems & - & - & - \\
\hline $\mathrm{L}$ & Alive & 9.1 & Normal & Nil \\
\hline M & Died day 7 (non-ketotic hyperglycinaemia) & - & - & - \\
\hline $\mathrm{N}$ & Died day 1 (severe rhesus disease) & - & - & - \\
\hline $\mathrm{O}$ & Alive & 9.0 & Delayed motor & Mild diplegia \\
\hline $\mathrm{P}$ & Alive & 7.3 & Normal & Nil \\
\hline $\mathrm{Q}$ & Alive & 7.5 & Delayed motor & Spastic diplegia \\
\hline $\mathrm{R}$ & Alive & 7.5 & Normal & Nil \\
\hline $\mathrm{s}$ & Alive & 7.0 & Normal & Nil \\
\hline $\mathrm{T}$ & Alive & 6.8 & Normal & Nil \\
\hline $\mathrm{U}$ & Alive & 6.4 & Normal & Nil \\
\hline
\end{tabular}

Six deaths were unrelated to brain pathology. Of the 16 survivors with isolated frontal horn cysts including subject B (late death): 10 had normal outcome and one (O) had mild diplegia ( 26 week gestation twin). Three subjects with additional subependymal haemorrhage that resolved had normal outcome. Two survivors who had mild cerebral palsy (subjects $\mathrm{F}$ and $\mathrm{Q}$ ) had other cranial abnormalities. 
A
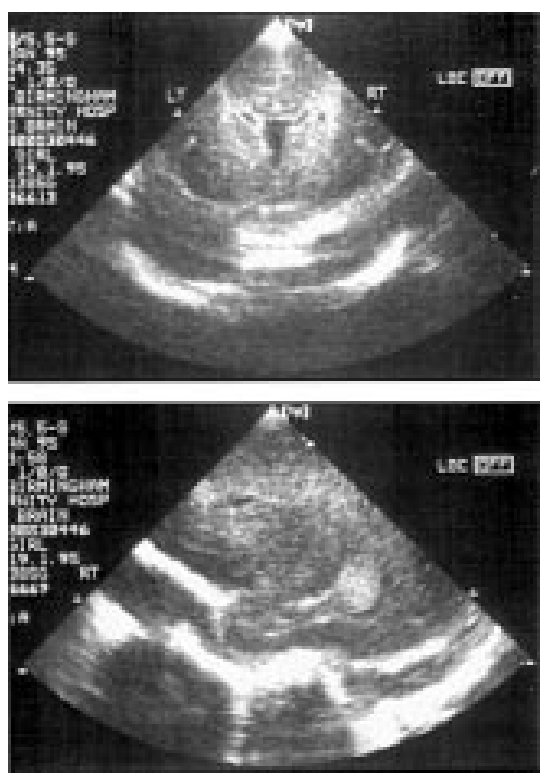

B

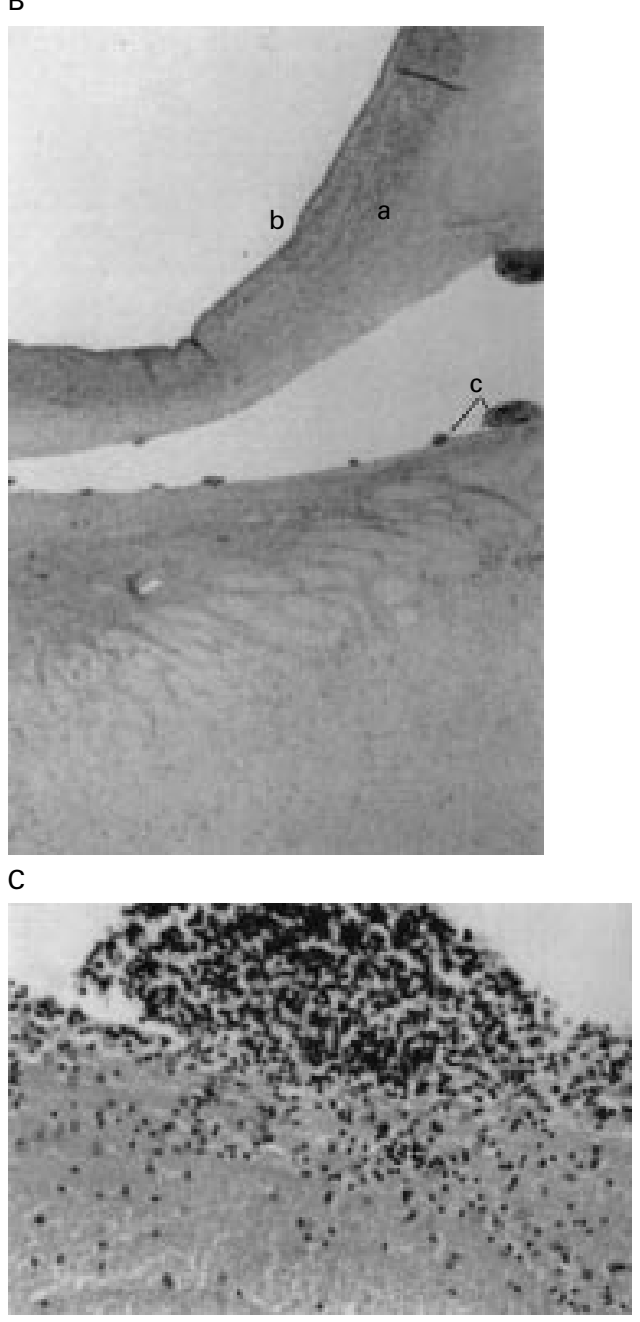

and $1.05 \%(3 / 285)$ for subjects of 33 weeks gestation and above. The incidence of $0.7 \%$ in our low birthweight series is in agreement with the results of Freudenberg, ${ }^{12}$ who reported congenital frontal unilateral or bilateral periventricular cysts in $0.7 \%$ of older infants examined by cranial ultrasound. These cysts have distinct ultrasound characteristics of both size and shape differentiating them from the cysts of PVL. Term infants are not routinely scanned as part of normal practice, and thus the true incidence of congenital frontal horn cysts in subjects over 33 weeks gestation is not clarified in our study.

Descriptions of infants with frontal horn cysts are few. A review of serial scans performed weekly on subjects who remained on the neonatal unit showed that, in most cases, the cysts appear to enlarge initially up to around 34 weeks gestation equivalent but then resolve completely by a median corrected age of 2 months (table 2, fig 2). Our findings are supported by a report by Thun-Hohenstein et $a l,{ }^{13}$ who described three infants born at term who had serial cranial ultrasound and magnetic resonance imaging (MRI) scans showing the presence of symmetrical periventricular cysts adjacent to the anterior horns. These lesions were not detectable by MRI at 3 months of age, and there was neither compensatory dilatation of the anterior horns nor secondary loss of white matter. The authors conclude that the appearance and location of these transient cysts are very different from those of the cystic changes that typically follow germinal matrix haemorrhage or PVL.

The suggestion by Thun-Hohenstein et $a l^{13}$ that these cysts may be present in babies of over 34 weeks gestation who do not have routine cranial ultrasound screening implies that they probably result from a common process that occurs early during neuroembryology. This would certainly account for the consistent anatomical position in our group. In another study, ${ }^{14} 34$ preterm infants, who were clinically and neurologically normal and with normal scans, had MRI performed at 30-37 weeks. In all these preterm infants, localised areas of high signal intensity ( $T_{1}$ weighted) and low signal ( $T_{2}$ weighted) images were seen adjacent to the frontal horns of the lateral ventricles similar in position to our frontal horn cysts, which faded with increasing age. These findings were no longer seen a month after term when 13 infants were examined by MRI.

The precise mechanism of events leading to the sonographic findings of smooth thin walled frontal horn cysts remains speculative. The proximity to the frontal horn of the lateral ventricles suggests that they may originate as diverticulae from the ventricles that become closed off or they are truly extraventricular, growing in the germinal matrix that surrounds the ventricle in early development, possibly as the result of local necrosis or entrapment of ependymal or choroidal cells. That they form and enlarge without distorting the surrounding tissues is consistent with a hamartomatous aetiology.

Fetal ependyma, unlike mature ependyma, is an active secretory structure for the programming of developmental events, ${ }^{15}$ and plays a role in neurogenesis, neuronal differentiation, axonal guidance, transport, and support. ${ }^{16} \mathrm{His}-$ tological examination suggests an ependymal origin of the frontal horn cyst (fig 3B). It is 
possible that the natural history of these cysts can be explained by the activity of the ependymal lining which is initially secretory, thus the cyst increases in size as the surrounding brain grows. Later atrophy, loss of ependymal cells, or loss of their secretory function results in decreased secretion and shrinkage of the cyst.

The evolution and clinical picture of cysts associated with PVL is different. Ultrasound progress of PVL echodensities shows that they evolve into multiple, small, irregular, septated cysts and are usually associated with cerebral atrophy. The extent of PVL cysts has also been correlated with volume loss on MRI during late infancy and the degree/type of neurological handicap. ${ }^{17}$ PVL is rare in utero, particularly as the vascularity of the brain differs in early gestation. ${ }^{18}$ The frontal horn cysts reported here are quite distinct in their anatomical position and always identified within the first few days of life. Their ultrasound characteristics and histological appearance are distinct from those of PVL cysts. Isolated subependymal cysts or pseudocysts occasionally seen on cranial sonograms of neonates differ in their anatomical position from frontal horn cysts. ${ }^{19}{ }^{20}$ Reports of other cystic lesions of varied origin also clearly differ from the characteristics of frontal horn cysts. ${ }^{21-24}$

Previous reports of outcome of frontal horn cysts are of small numbers and short term follow up. We found normal neurodevelopmental outcome on extended follow up in 10 survivors and one subject $(\mathrm{O})$ who had another cause of diplegia (a twin born at 26 weeks). We acknowledge that more subtle cognitive changes $^{25}$ cannot be excluded in this population.

SUMMARY

Routine screening cranial ultrasound performed regularly in preterm subjects under 33 weeks gestation or under $1500 \mathrm{~g}$ birth weight has identified frontal horn cysts that are quite distinct from PVL cysts. We suggest that they are a benign variant of normal neurodevelopment, are lined by ependyma, and resolve spontaneously. Subjects with isolated lesions appear to have normal neurodevelopmental outcome.

Author's note

If readers would like to see a colour version of figures $3 \mathrm{~B}$ and $\mathrm{C}$ they can contact DrPal (BRPal@fsmail.net).

We are grateful to $\mathrm{G}$ Cattell for her excellent scan images, $\mathrm{K}$ Rose for helping with the typescript, and Dr D Castling for helpful comments. We also thank Mrs Wendy Wright, Medica Illustration, City Hospital for excellent image reproduction/ illustrations.

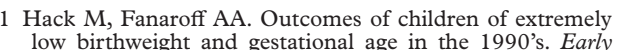
low birthweight and gestation

2 de Vries LS, Rademaker KJ, Groenendaal F, et al Correlation between neonatal cranial ultrasound, MRI in infancy and neurodevelopmental outcome in infants with a large intraventricular haemorrhage with or without unilateral parenchymal involvement. Neuropediatrics 1998;29:180-8

3 Wilson-Costello D, Borawski E, Friedman H, et al. Perinatal correlates of cerebral palsy and other neurological impairment among very low birth weight children. Paediatrics 1998;102:315-22.

4 Harding D, Kuschel C, Evans N. Should preterm infants born after 29 weeks gestation be screened for intraventricular haemorrhage? $\mathcal{F}$ Paediatr Child Health 1998;34:579.

5 Borch K, Greisen G. Blood flow distribution in the normal human preterm brain. Pediatr Res 1998;43:28-33.

6 McMenamin JB, Shackelford GD, Volpe JJ. Outcome of neonatal intraventricular haemorrhage with periventricular echodense lesions. Ann Neurol 1984;15:285.

7 Rushton DI, Preston PR, Durbin GM. Structure and evolution of echodense lesions in the neonatal brain. A combined ultrasound and necropsy study. Arch Dis Child 1985;60:798-808

8 Fawer CL, Diebold P, Calame A. Periventricular leucomalacia and neurodevelopmental outcome in preterm infants. Arch Dis Child 1987;62:30-6.

9 Keller MS, DiPietro MA, Teele RL, et al. Periventricular cavitations in the first week of life. American fournal of Neuroradiology 1987;8:291.

10 Sudakoff GS, Mitchell DG, Stanley C, et al. Frontal periventricular cysts on the first day of life: a one year clinical follow-up and its significance. $f$ Ultrasound Med 1991;10:25-30.

11 Ellenberg JH, Nelson KB. Early recognition of infants at high risk for cerebral palsy: examination at age four high risk for cerebral palsy: examination at
months. Dev Med Child Neurol 1981;23:705-16.

12 Freudenberg V. Kongenitale subependymale Zysten der zerebralen Seitenventrikel Ultraschall Klin Prax 1988;3:86-8.

13 Thun-Hohenstein L, Forster I, Kunzle C, et al. Transient bifrontal solitary perventricular cysts in term neonates. Neuroradiology 1994;36;241-4.

14 Van Wezel-Meijler G, van der Knaap MS, Sie LT, et al. Magnetic resonance imaging of the brain in premature infants during the neonatal period. Normal phenomena and reflection of mild ultrasound abnormalities. Neuropediatrics 1998;29:89-96.

15 Sarnat HB. Ependymal reactions to injury. A review. 7 Neuropathol Exp Neurol 1995;54:1-15.

16 Bruni JE. Ependymal development, proliferation and functions: a review. Microscopy Research and Technique 1998;41:2-13.

17 Guzetta F, Shackelford GD, Volpe S, et al. Periventricular intraparenchymal echodensities in the premature newborn: critical determinant of neurologic outcome. Pediatrics 1986;78:6.

18 Bowerman RA, Donn SM, Silver TM, et al. Natural history of neonatal periventricular/intraventricular haemorrhage and its complications: sonographic observations. AfR Am f Roentgenol 1984;143:1041

19 Rademaker KJ, DeVries LS, Barth PG. Subependymal pseudocysts: ultrasound diagnosis and findings at followup. Acta Paediatr 1993;82:394-9.

20 Larcos G, Gruenewald SM, Lui K. Neonatal subependymal cysts detected by sonography: prevalence, sonographic finding and clinical significance. AfR Am f Roentgenol 1994;162:953-6.

21 Weidenheim KM, Bodhireddy SR, Nuovo GJ, et al. Multicystic encephalopathy: review of eight cases with Multicystic encephalopathy: review of eight cases with
etiologic considerations. f Neuropathol Exp Neurol 1995;54:268-75.

22 Stadlan EM, Sung, JH. Congenital rubella encephalopathy. F Neuropathol Exp Neurol 1967;26:115.

23 Cohen HL, Sloves JH, Laungani S, et al. Neurosonographic findings in full-term infants born to maternal cocaine abusers; visualization of subependymal and periventricular cysts. F Clin Ultrasound 1994;22:327-33.

24 Sarnat HB, Darwish HZ, Barth PG, et al. Ependymal abnormalites in lissencephaly/pachygyria. $\mathcal{F}$ Neuropathol Exp Neurol 1993;52:525-41.

25 Marin-Padilla M. Developmental neuropathology and impact of perinatal brain damage. I. Haemorrhagic lesions of neocortex. F Neuropathol Exp Neurol 1996;55:758-73. 